\title{
A non-destructive genotyping system from a single seed for marker-assisted selection in watermelon
}

G. Meru' ${ }^{1}$ D. McDowell ${ }^{2}$, V. Waters ${ }^{1}$, A. Seibel ${ }^{1}$, J. Davis ${ }^{3}$ and

C. McGregor ${ }^{1}$

${ }^{1}$ Department of Horticulture, University of Georgia, Athens, GA, USA

${ }^{2}$ Young Scholars Program, College of Agriculture and Environmental Sciences, University of Georgia, Athens, GA, USA

${ }^{3}$ Department of Experimental Statistics, University of Georgia, Griffin, GA, USA

Corresponding author: G. Meru

E-mail: merujeff@uga.edu

Genet. Mol. Res. 12 (1): 702-709 (2013)

Received June 25, 2012

Accepted August 7, 2012

Published March 11, 2013

DOI http://dx.doi.org/10.4238/2013.March.11.18

\begin{abstract}
Genomic tools for watermelon breeding are becoming increasingly available. A high throughput genotyping system would facilitate the use of DNA markers in marker-assisted selection. DNA extraction from leaf material requires prior seed germination and is often time-consuming and cost prohibitive. In an effort to develop a more efficient system, watermelon seeds of several genotypes and various seed sizes were sampled by removing $1 / 3$ or $1 / 2$ sections from the distal ends for DNA extraction, while germinating the remaining proximal parts of the seed. Removing $1 / 3$ of the seed from the distal end had no effect on seed germination percentage or seedling vigor. Different DNA extraction protocols were tested to identify a method that
\end{abstract}


could yield DNA of sufficient quality for amplification by polymerase chain reaction. A sodium dodecyl sulfate extraction protocol with $1 \%$ polyvinylpyrrolidone yielded DNA that could be amplified with microsatellite primers and was free of pericarp contamination. In this study, an efficient, non-destructive genotyping protocol for watermelon seed was developed.

Key words: DNA; Sodium dodecyl sulfate; Germination; Vigor; Polyvinylpyrrolidone

\section{INTRODUCTION}

The application of DNA markers to aid the selection of important traits in plant breeding is routine for many crops (von Post et al., 2003; Gao et al., 2008). Leaf-based genotyping systems for marker-assisted selection (MAS) are resource-intensive, requiring prior germination of seeds and the collection and storage of leaf samples in expensive, ultralow-temperature freezers (Kang et al., 1998; Gao et al., 2008). Seed-based genotyping systems provide an appealing alternative that saves resources and allows breeders to select suitable individuals prior to planting (von Post et al., 2003; Gao et al., 2008). This method has been adopted for several crops, including barley (von Post et al., 2003), maize (Gao et al., 2008), soy bean (Kamiya and Kiguchi, 2003), wheat (Abd-Elsalam et al., 2011), and rice (Kang et al., 1998). To be useful, a non-destructive sampling technique that does not affect the germination potential of remnant seed embryos must be developed and the DNA extracted from the seed must be of sufficient quantity and quality to allow genotypic analysis. DNA extractions from seed can be problematic and DNA of low quality and quantity is observed frequently (AbdElsalam et al., 2011). Moreover, the extracted DNA must be devoid of pericarp contamination, which can lead to genotyping errors (Gao et al., 2008). Here we describe a non-destructive seedbased genotyping system for watermelon.

\section{MATERIAL AND METHODS}

\section{Plant materials, seed sampling, and germination test}

Three watermelon genotypes (Sugar Baby, Charleston Gray, and Florida Giant) obtained from Reimer Seed Company (Mount Holly, NC, USA) were chosen due to their different seed sizes. Seed samples for DNA extraction were obtained by removing $1 / 3$ or $1 / 2$ of the distal portions with a steel blade (Figure 1). The remaining proximal portions were germinated in cells $(5.98 \times 3.68 \times 4.69 \mathrm{~cm})$ filled with Fafard 3B soil amended with Osmocote Classic ( $1.38 \mathrm{~g} / \mathrm{kg} \mathrm{N}, 1.38 \mathrm{~g} / \mathrm{kg} \mathrm{P}, 1.38 \mathrm{~g} / \mathrm{kg} \mathrm{K})$ in the greenhouse (14-h light $/ 10$-h dark cycle, $22^{\circ}-32^{\circ} \mathrm{C}$ ). Germination data and individual plant height (indicator of vigor) were measured 15 days after planting (DAP). The experiment was carried out in July 2011 and repeated in August and December of the same year with 24 seeds for each treatment-cultivar combination in each experiment. 


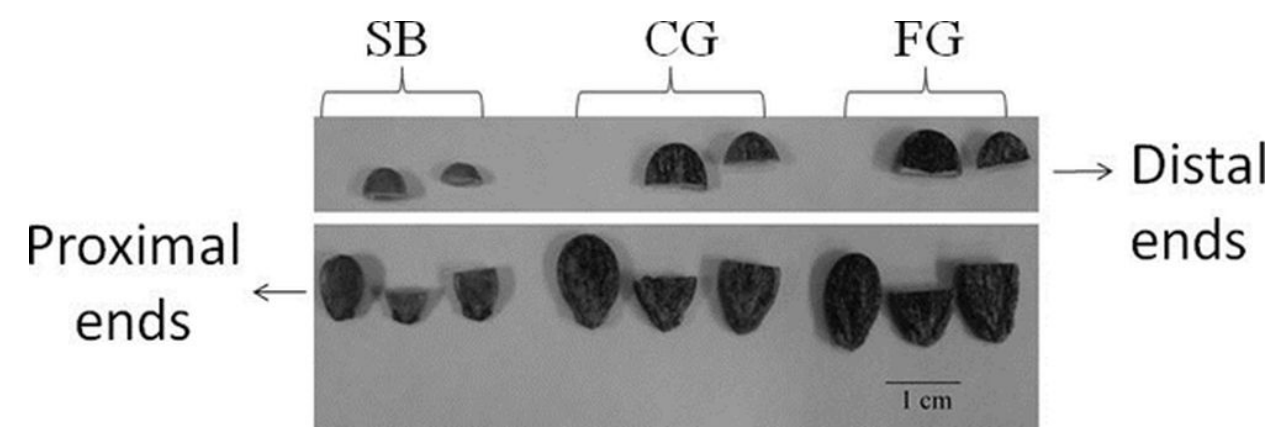

Figure 1. Uncut and cut seeds from Sugar Baby (SB), Charleston Gray (CG) and Florida Giant (FG) indicating the size of proximal and distal parts.

\section{DNA extraction and simple sequence repeat (SSR) analysis}

Cut seeds were placed in individual tubes on a 96-well plate (Greentree Scientific, Bloomfield, NY, USA), immersed in liquid nitrogen for $5 \mathrm{~min}$, then ground using 5-mm beads (Qiagen Inc., Valencia, CA, USA) in a Tissuelyser II (Qiagen) for $5 \mathrm{~min}$ at $30 \mathrm{~Hz} / \mathrm{s}$. Four DNA extraction buffers were tested using two different protocols.

Protocol 1 (modified from McGregor et al., 2000; Gao et al., 2008): samples were incubated in $450 \mu \mathrm{L} 1 \%$ cetyltrimethylammonium bromide (CTAB), $1 \%$ sarcosyl, or $1 \%$ sodium dodecyl sulfate (SDS) in a water bath at $65^{\circ} \mathrm{C}$ for $30 \mathrm{~min}$. Each buffer also included $100 \mathrm{mM}$ Tris- $\mathrm{HCl}, \mathrm{pH} 7.5,700 \mathrm{mM} \mathrm{NaCl}, 50 \mathrm{mM}$ EDTA, $\mathrm{pH} 8$, and $0.2 \%(\mathrm{v} / \mathrm{v}) \beta$-mercaptoethanol, which was added just before incubation. An equal volume of chloroform-isoamyl alcohol (24:1) was added and samples were centrifuged at $2465 \mathrm{~g}$ for $10 \mathrm{~min}$ at room temperature. The supernatant $(300 \mu \mathrm{L})$ was transferred to clean tubes and $0.6 \mathrm{X}$ volume cold isopropanol was added. DNA was allowed to precipitate for $30 \mathrm{~min}$ at $-20^{\circ} \mathrm{C}$ and collected by centrifugation at $2465 \mathrm{~g}$ for $10 \mathrm{~min}$ at room temperature. The pellets were washed twice with cold $70 \%$ ethanol and allowed to air dry before suspension in $50 \mu \mathrm{L}$ Tris-EDTA.

Protocol 2 [polyvinylpyrrolidone (PVP) + SDS] (modified from Abd-Elsalam et al., 2011): ground samples were incubated in $450 \mu \mathrm{L} 0.5 \%$ SDS, $1 \%$ PVP, $200 \mathrm{mM}$ Tris-HCl, $\mathrm{pH}$ $7.5,250 \mathrm{mM} \mathrm{NaCl}, 25 \mathrm{mM}$ EDTA, $\mathrm{pH} 8$, and $0.2 \%(\mathrm{v} / \mathrm{v}) \beta$-mercaptoethanol in a water bath at $65^{\circ} \mathrm{C}$ for $30 \mathrm{~min}$. NaOAc $(0.3 \mathrm{X}$ volume, $3 \mathrm{M})$ was added to each tube, then centrifuged at $2465 \mathrm{~g}$ for $10 \mathrm{~min}$. The supernatant was transferred to a clean tube and an equal volume of cold isopropanol was added. DNA was allowed to precipitate for $10 \mathrm{~min}$ at room temperature and collected by centrifugation at $2465 \mathrm{~g}$ for $10 \mathrm{~min}$ at room temperature. The DNA pellets were washed and suspended as previously described.

DNA concentration and quality were determined on a NanoDrop 8000 (Thermo Scientific, USA) and by agarose gel electrophoresis. Amplification of all samples was initially tested using internal transcribed spacer (ITS) primers (Blattner, 1999). An SSR marker (MCPI-13) (Joobeur et al., 2006) was used to determine the presence of pericarp contamination by amplifying DNA obtained from seed (SDS + PVP) and from the corresponding leaf samples of a segregating population of $30 \mathrm{~F}_{2}$ plants. The amplicons were separated on an $\mathrm{ABI}$ 
3730 capillary sequencer (Applied Biosystems, USA) at the Georgia Genomics Facility and the output was analyzed using Genemapper 4.0 (Applied Biosystems).

\section{Statistical analysis}

Data were analyzed using the PROC GLM procedure of SAS (SAS Institute Inc., 1999) and the means of the variables tested were analyzed by the Tukey honest significance test (Ott and Longnecker, 2001).

\section{RESULTS}

\section{Germination percentage and plant vigor}

There was no significant difference $(\alpha=0.05)$ in germination percentage between the $2 / 3$ proximal ends and uncut controls at 15 DAP for any of the cultivars tested (Table 1 ). However, there was a significant difference in germination percentage between samples in which $1 / 2$ of the distal ends were removed for DNA extraction and uncut controls for the Sugar Baby cultivar (Table 1), which had the smallest seed. Similarly, seedling heights at 15 DAP did not differ significantly between the $2 / 3$ proximal ends and uncut controls for any of the cultivars tested (Table 1). However, removing $1 / 2$ of the distal ends for DNA extraction from Sugar Baby seeds significantly affected the plant height (vigor) in comparison to uncut controls. The remainder of the experiment was therefore carried out using $1 / 3$ distal ends.

\begin{tabular}{|c|c|c|c|c|c|c|}
\hline \multirow[t]{3}{*}{ Treatments (proximal ends) } & \multicolumn{6}{|c|}{ Cultivars } \\
\hline & \multicolumn{2}{|c|}{ Charleston Gray } & \multicolumn{2}{|c|}{ Florida Giant } & \multicolumn{2}{|c|}{ Sugar Baby } \\
\hline & $\begin{array}{c}\text { Germination } \\
(\%)\end{array}$ & $\begin{array}{l}\text { Height } \\
(\mathrm{cm})\end{array}$ & $\begin{array}{c}\text { Germination } \\
(\%)\end{array}$ & $\begin{array}{c}\text { Height } \\
(\mathrm{cm})\end{array}$ & $\begin{array}{c}\text { Germination } \\
(\%)\end{array}$ & $\begin{array}{l}\text { Height } \\
(\mathrm{cm})\end{array}$ \\
\hline Uncut control & 87.5 & 6.8 & 94.4 & 6.5 & 79.1 & 4.9 \\
\hline Two third & 91.6 & 6.7 & 98.6 & 7.1 & 83.3 & 4.2 \\
\hline Half & 87.5 & 6.2 & 93.0 & 6.3 & $61.1^{*}$ & $3.4^{*}$ \\
\hline
\end{tabular}

$* \mathrm{P}<0.05$.

\section{DNA quality, quantity, and genotypic analysis}

DNA was obtained with all 4 buffers, regardless of protocol (Figure 2). The SDS + PVP buffer yielded significantly higher amounts of DNA than the other buffers (Table 2). For Charleston Gray, the DNA yield per single seed sample ranged from 9.96-15.95 $\mu \mathrm{g}$, for Florida Giant, 5.75-20.6 $\mu \mathrm{g}$, and for Sugar Baby, 1.7-4.8 $\mu \mathrm{g}$. The mean absorbance at 260/280 $\mathrm{nm}$ ranged from 0.88 for CTAB buffer to 1.92 for SDS + PVP (Table 2). The mean absorbance at $260 / 230 \mathrm{~nm}$ ranged from 0.34 for CTAB buffer to 0.6 for $0.5 \%$ SDS buffer (Table 2). Only DNA from the SDS + PVP method could be amplified consistently with ITS primers (Figure 
3). Comparison between MCPI-13 SSR genotypic profiles from seed and leaf-derived DNA from an $\mathrm{F}_{2}$ population showed no evidence of pericarp contamination (Table 3).

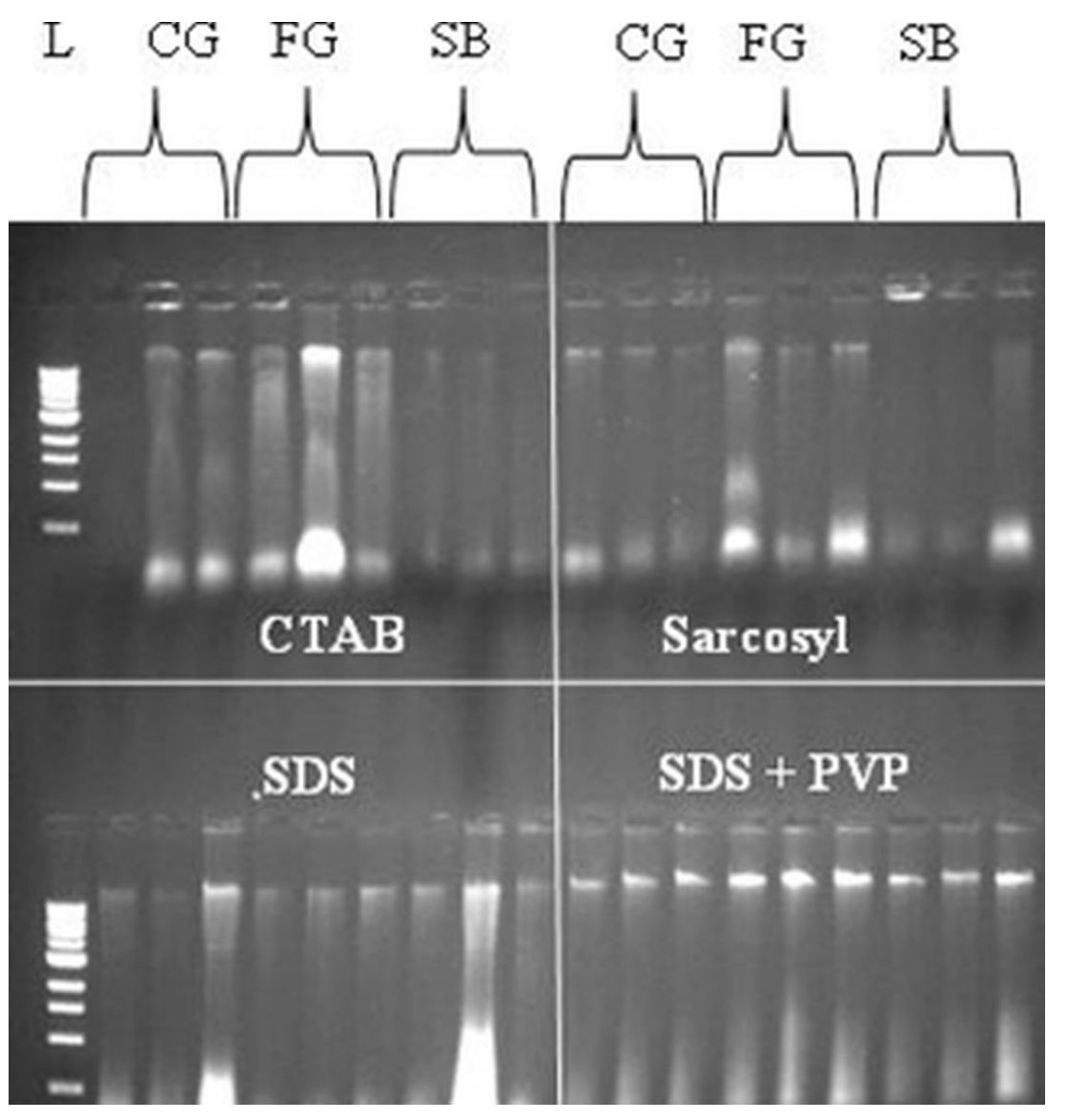

Figure 2. Electrophoresis on $0.8 \%$ agarose gel of DNA extracted from Charleston Gray (CG), Florida Giant (FG) and Sugar Baby (SB) watermelon seeds using four different extraction buffers. Lane $L=1-\mathrm{kb}$ DNA size marker (Promega, San Luis Obispo, CA, USA). CTAB = cetyltrimethylammonium bromide; SDS = sodium dodecyl sulfate; PVP $=$ polyvinylpyrrolidone.

Table 2. Properties of DNA extracted using four different buffers.

\begin{tabular}{lccc}
\hline Buffers & DNA concentration $(\mathrm{ng} / \mu \mathrm{L})$ & $\mathrm{A}_{260 / 280}$ & $\mathrm{~A}_{260 / 230}$ \\
\hline CTAB & 170.1 & $0.88^{*}$ & $0.34^{*}$ \\
SAR & 184.4 & 1.38 & 0.49 \\
SDS & 121.3 & 1.51 & 0.60 \\
SDS + PVP & $261.9^{*}$ & 1.92 & 0.53 \\
\hline
\end{tabular}

All DNA samples were dissolved in $50 \mu \mathrm{L}$ TE. CTAB = cetyltrimethylammonium bromide; SAR = sarcosyl; SDS $=$ sodium dodecyl sulfate; $\mathrm{PVP}=$ polyvinylpyrrolidone. ${ }^{*} \mathrm{P}<0.05$. 


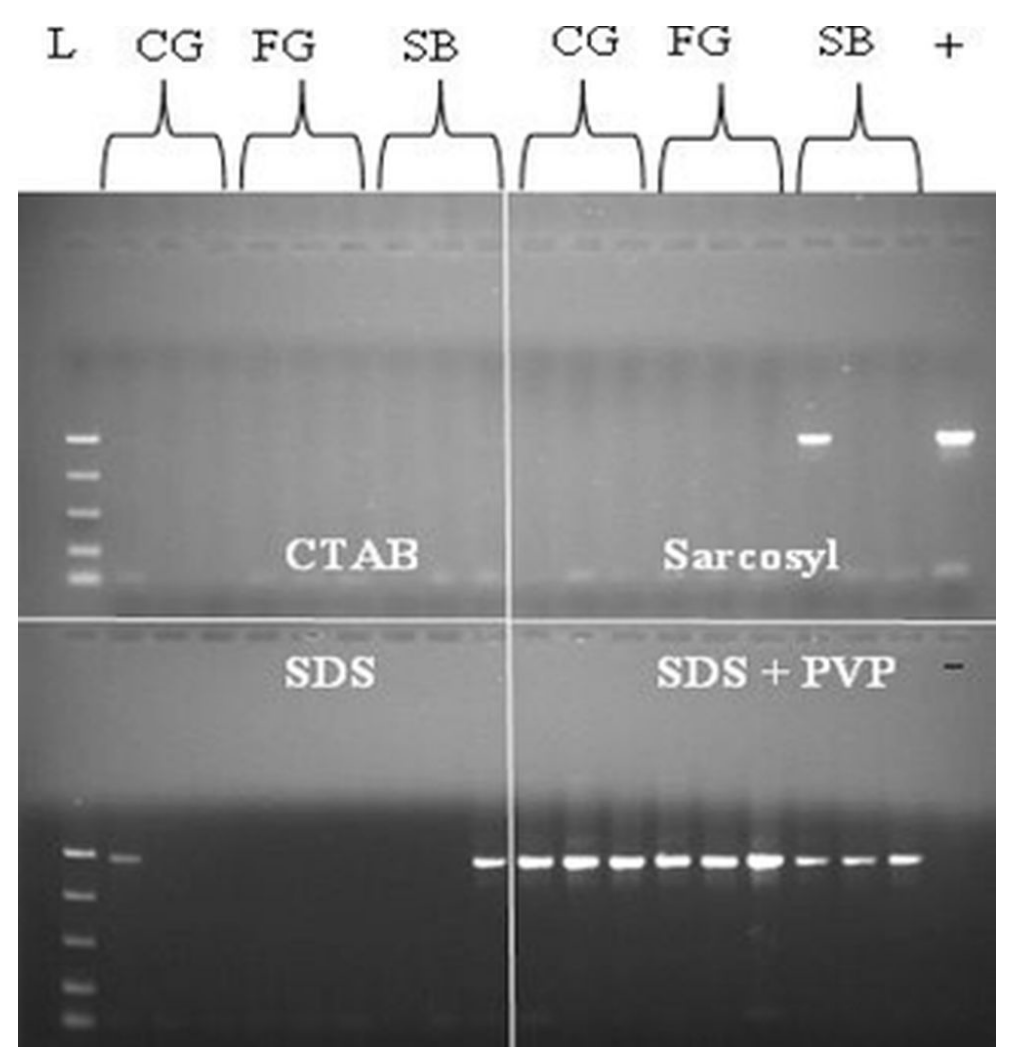

Figure 3. PCR amplification of Charleston Gray (CG), Florida Giant (FG) and Sugar Baby (SB) DNA samples extracted using different extraction buffers using internal transcribed spacer primers (Blattner, 1999) separated on a $1.5 \%$ agarose gel. Lane $L=100$-bp DNA size marker (Promega, San Luis Obispo, CA, USA). For abbreviations, see legend to Figure 2.

Table 3. Alleles observed after MCPI-13 SSR (Joobeur et al., 2006) amplification of DNA isolated from leaves or seeds in a segregating $\mathrm{F}_{2}$ population.

\begin{tabular}{lcc}
\hline & \multicolumn{2}{c}{ SSR alleles } \\
\cline { 2 - 3 } & Leaf & Seed \\
\hline Parent 1 & $222 / 222$ & $222 / 222$ \\
Parent 2 & $210 / 210$ & $210 / 210$ \\
$\mathrm{~F}_{1}$ & $210 / 222$ & $210 / 222$ \\
$\mathrm{~F}_{2}$ (subset) & $210 / 210$ & $210 / 210$ \\
& $222 / 222$ & $222 / 222$ \\
& $222 / 222$ & $222 / 222$ \\
& $210 / 210$ & $210 / 210$ \\
& $222 / 222$ & $222 / 222$ \\
& $210 / 210$ & $210 / 210$ \\
& $222 / 222$ & $222 / 222$ \\
& $210 / 210$ & $210 / 210$ \\
& $222 / 222$ & $222 / 222$ \\
\hline
\end{tabular}




\section{DISCUSSION}

In order to adopt a seed-based genotyping system for watermelon, a non-destructive sampling method is imperative. The germination percentage and vigor of the resulting seedling depends on the integrity of the embryo and the availability of nutrition after sampling, respectively (Gao et al., 2008). In this study, sampling half of the seeds for DNA extraction reduced germination percentage and plant vigor for the small-seeded cultivar, Sugar Baby. This is an indication that sampling large portions of distal ends from small-seeded genotypes may deplete the energy reserves required for germination and growth. Gao et al. (2008) reported similar results in maize endosperm samples. In the current experiment, removal of the $1 / 3$ distal portion of the seed for DNA extraction did not influence these parameters. DNA yields ranged from 1.7-20.6 $\mu \mathrm{g}$ and are sufficient for analysis of 170-2000 PCRs, sufficient for most MAS applications. Although all the DNA extraction buffers yielded DNA, consistent PCR amplification was only possible from DNA extracted using the SDS + PVP method. This buffer also gave the best $\mathrm{A}_{260 / 280}$ (1.92) values, which indicate good-quality DNA (Thermo Scientific, 2008). Other buffers had $\mathrm{A}_{260 / 280}$ values of 0.88-1.51, indicating protein contamination (Thermo Scientific, 2008). Although all buffers yielded DNA samples with very low $\mathrm{A}_{260 / 230}$ values, indicating the presence of co-purified contaminants such as polysaccharides (Gao et al., 2008; Thermo Scientific, 2008), this did not seem to influence PCR success when using the SDS + PVP method. PVP absorbs polyphenols and polysaccharides (Schween et al., 2002), and has been used in other studies to eliminate PCR inhibitors (Li et al., 2007).

To investigate possible retention of maternal tissue from the pericarp in the extracted DNA, a polymorphic SSR marker was used to detect genotyping errors in a segregating $\mathrm{F}_{2}$ population. Pairwise comparison of cotyledon genotypes and corresponding leaf genotypes showed no contamination with maternal alleles in the embryos. Pericarp contamination may be detected if the cotyledon genotype is heterozygous while the leaf genotype is homozygous (Gao et al., 2008).

In addition to its application for MAS, this method will be a suitable alternative to leaf-based genotyping for other watermelon crop applications such as genetic diversity studies, DNA fingerprinting, and tests for varietal purity.

\section{ACKNOWLEDGMENTS}

We recognize the assistance of our student workers in seed sampling and data collection. Research supported by the University of Georgia, College of Agricultural and Environmental Sciences, Young Scholars Program.

\section{REFERENCES}

Abd-Elsalam K, Bahkali A, Moslem M, Amin OE, et al. (2011). An optimized protocol for DNA extraction from wheat seeds and loop-mediated isothermal amplification (LAMP) to detect Fusarium graminearum contamination of wheat grain. Int. J. Mol. Sci. 12: 3459-3472.

Blattner FR (1999). Direct amplification of the entire ITS region from poorly preserved plant material using recombinant PCR. Biotechniques 27: 1180-1186.

Gao S, Martinez C, Skinner D, Krivanek A, et al. (2008). Development of a seed DNA-based genotyping system for marker-assisted selection in maize. Mol. Breed. 22: 477-494.

Joobeur T, Gusmini G, Zhang X, Levi A, et al. (2006). Construction of a watermelon BAC library and identification of 
SSRs anchored to melon or Arabidopsis genomes. Theor. Appl. Genet. 112: 1553-1562.

Kamiya M and Kiguchi T (2003). Rapid DNA extraction method from soybean seeds. Breed. Sci. 53: 277-279.

Kang HW, Cho YG, Yoon U and Eun MY (1998). A rapid DNA extraction method for RFLP and PCR analysis from a single dry seed. Plant Mol. Bio. Rep. 16: 1-9.

Li JT, Yang J, Chen DC, Zhang XL, et al. (2007). An optimized mini-preparation method to obtain high-quality genomic DNA from mature leaves of sunflower. Genet. Mol. Res. 6: 1064-1071.

McGregor CE, Lambert CA, Greyling MM, Louw JH, et al. (2000). A comparative assessment of DNA fingerprinting techniques (RAPD, ISSR, AFLP and SSR) in tetraploid potato (Solanum tuberosum L.) germplasm. Euphytica 113: 135-144.

Ott RL and Longnecker M (2001). An Introduction to Statistical Methods and Data Analysis. 5th edn. Duxbury Press, Pacific Grove.

SAS Institute Inc. (1999). SAS/STAT User's Guide, Version 7-1. SAS Institute Inc., Cary.

Schween G, Fleig S and Reski R (2002). High-throughput-PCR screen of 15,000 transgenic Physcomitrella plants. Plant Mol. Biol. Rep. 20: 43-47.

Thermo-Scientific (2008). Nanodrop 1000 Spectrophotometre V3.7 Users Manual. Thermo Fisher Scientific Inc., Wilmington.

von Post R, von Post L, Dayteg C, Nilsson M, et al. (2003). A high-throughput DNA extraction method for barley seed. Euphytica 130: 255-260. 